\title{
Cyrtandra argentii, a new species of Cyrtandra (Gesneriaceae) from the Philippines, and a review of the $C$. villosissima group
}

\author{
Jay Edneil C. OLIVAR ${ }^{1, *}$, Hannah J. ATKINS ${ }^{2}$, Frank HAUENSCHILD ${ }^{1,3}$ \& \\ Alexandra N. MUELLNER-RIEHL ${ }^{1,4}$ \\ ${ }^{1}$ Department of Molecular Evolution and Plant Systematics \& Herbarium (LZ), Institute of Biology, \\ Leipzig University, Johannisallee 21-23, 04103 Leipzig, Germany. \\ ${ }^{2}$ Royal Botanic Garden Edinburgh, 20a Inverleith Row, EH3 5LR, United Kingdom. \\ ${ }^{3}$ Leipzig University, Centre for Teacher Training and School Research, Prager Str. 38-40, \\ 04317 Leipzig, Germany. \\ ${ }^{4}$ German Centre for Integrative Biodiversity Research (iDiv) Halle-Jena-Leipzig, Leipzig, Germany. \\ *Corresponding author: jay_edneil.olivar@uni-leipzig.de \\ 2Email: HAtkins@rbge.org.uk \\ ${ }^{3}$ Email: frank.hauenschild@uni-leipzig.de \\ ${ }^{4}$ Email: muellner-riehl@uni-leipzig.de
}

\begin{abstract}
Cyrtandra argentii Olivar, H.J.Atkins \& Muellner sp. nov., endemic to the Philippines and named after George Argent, is herein described and illustrated. Collections associated with this new species are often confused with three other species, namely C. ferruginea Merr., C. villosissima Merr., and $C$. hirtigera H.J.Atkins \& Cronk. Distinguishing characters including keys, updated descriptions, distribution maps, and photos of live specimens are provided to aid identification of the four species. Following the International Union for the Conservation of Nature (IUCN) criteria, C. argentii sp. nov. is considered to be Near Threatened (NT) due to its distribution in a zone susceptible to anthropogenic pressure and the lack of any formal protection.
\end{abstract}

Keywords. Cyrtandra, C. argentii sp. nov., George Argent, IUCN, Philippines.

Olivar J.E.C., Atkins H.J., Hauenschild F. \& Muellner-Riehl A.N. 2020. Cyrtandra argentii, a new species of Cyrtandra (Gesneriaceae) from the Philippines, and a review of the C. villosissima group. European Journal of Taxonomy 676: 1-15. https://doi.org/10.5852/ejt.2020.676

\section{Introduction}

Cyrtandra J.R.Forst. \& G.Forst. (Forster \& Forster 1775) is the largest genus of ca 800 spp. in the family Gesneriaceae Rich. \& Juss. (de Candolle 1816). The genus is recognized by possessing two fertile stamens and fruits that are indehiscent, either hard capsules or fleshy berries (Cronk et al. 2005; Atkins et al. 2013). Members of the genus exhibit diverse growth forms, ranging from herbs and shrubs, to climbers and small trees distributed throughout the Malesian region and across the Pacific (Johnson et al. 2017; Kartonegoro et al. 2018). Species of Cyrtandra are important rainforest elements, thriving in habitats with high humidity, low light intensity, and constant moisture supply (Gillett 1967). Despite a 
continuous distributional range, the genus shows high levels of local endemism exhibiting high degrees of ecological specialization, making it an ideal candidate to address hypotheses on speciation, patterns of diversification, and community assembly (Atkins et al. 2001; Bramley et al. 2004; Clark et al. 2009; Johnson et al. 2019).

In recent years, several studies (Wagner et al. 2001; Bramley et al. 2003; Atkins 2004; Bramley 2005; Lorence \& Perlman 2007; Bone \& Atkins 2013; Johnson 2017; Kartonegoro et al. 2018; Atkins et al. 2019; Nishii et al. 2019) have led to an increase in numbers of species of Cyrtandra. These studies emphasized the urgency to document and understand the biodiversity of cyrtandras before they succumb to anthropogenic pressures. However, little is still known about the taxonomy of members in areas which are considered centers of biodiversity for the genus. Atkins et al. (2013) estimated a high species richness on Borneo, in the Philippines and on New Guinea. Understanding species boundaries of members from these areas is becoming increasingly important for examining biological trends of adaptation and speciation, and facilitating ecosystem and species conservation assessments.

For the Philippines, a comprehensive account of Cyrtandra spp. was published by Merrill (1922) in his An Enumeration of Philippine Flowering Plants noting 83 species, of which only C. oblongifolia C.B.Clarke (de Candolle \& de Candolle 1883) was listed as not endemic. Atkins \& Cronk (2001) revised Philippine cyrtandras from the island of Palawan, describing seven new species and indicating that C. elatostemoides Elmer (Elmer 1913) is also found on Borneo. Both accounts were considered in an updated checklist of Philippine cyrtandras available through 'Co's Digital Flora of the Philippines' (Pelser et al. 2011 onwards). A taxonomic revision of Philippine cyrtandras, however, addressing species boundaries, distributions, and descriptions is yet to be achieved.

Atkins \& Cronk (2001) noted the striking vegetative similarities between C. villosissima Merr. (Merrill 1906) from the island of Mindanao and a 1922 collection by Merrill from the island of Palawan which he labeled C. woodii Merr. ined. with no accompanying publication. Similarities include an erect suffrutescent habit, and large leaves that are slightly falcate and densely hirsute. However, in Merrill's 1922 Enumeration of Philippine Plants the name C. woodii did not appear, and the distribution of C. villosissima was extended to Palawan, which according to Atkins \& Cronk (2001) seems to provide evidence for Merrill's decision to 'sink' his $C$. woodii into C. villosissima. Increased sampling in the locality of $C$. woodii led to collections with reproductive structures that show the species' distinctness from C. villosissima. This ultimately led to the description of C. hirtigera H.J.Atkins \& Cronk (Atkins \& Cronk 2001), favoring a new name to prevent confusion with the Bornean C. woodsii B.L.Burtt (Burtt 1970). In the course of an ongoing research project, aimed at the taxonomic revision of Philippine cyrtandras, it was found that $C$. ferruginea Merr. (Merrill 1915) and a series of collections from Mindoro and the Aurora Province housed at the Royal Botanic Garden Edinburgh (RBGE) share similar vegetative characters with $C$. villosissima. As a result, identification of several herbarium specimens was found to be intermediate between $C$. villosissima and C. ferruginea, without a clear distinction being possible between the two when no additional reproductive characters were present. In this paper, species sharing the character combination of an erect suffrutescent habit and large leaves that are slightly falcate and densely hirsute, are referred to as the $C$. villosissima group. Members of this group are $C$. ferruginea, C. hirtigera, $C$. villosissima, and $C$. argentii sp. nov. Our study aims at clarifying the differences between these species through keys and photographs, and provides a description and diagnosis for a new species often misidentified as either $C$. ferruginea, $C$. villosissima, or $C$. hirtigera.

\section{Material and methods}

Data for this study were derived from herbarium specimens including their corresponding field notes, photographs, and field observations. Whenever available, living collections housed at the Royal Botanic Garden Edinburgh (RBGE) were consulted and reproductive characters and measurements were 
Table 1. Diagnostic characters separating the four studied species.

\begin{tabular}{|c|c|c|c|c|}
\hline & $\begin{array}{l}\text { C. argentii } \\
\text { sp. nov. }\end{array}$ & C. ferruginea & C. hirtigera & C. villosissima \\
\hline Distribution & $\begin{array}{l}\text { Sierra Madre } \\
\text { Mountain Range to } \\
\text { Mindoro Island }\end{array}$ & $\begin{array}{l}\text { Catanduanes, Mt } \\
\text { Bulusan, Mt Isarog, } \\
\text { Mt Mayon }\end{array}$ & Palawan & $\begin{array}{l}\text { Negros Island to } \\
\text { Mindanao Island }\end{array}$ \\
\hline Indumentum color & White all throughout & Ferruginous & Crimson or pale white & Ferruginous \\
\hline Leaf symmetry & Subequal & Anisophyllous & Subequal & Subequal \\
\hline Inflorescence type & Compound cyme & Cyme & Cyme & Cyme \\
\hline $\begin{array}{l}\text { Inflorescence } \\
\text { attachment }\end{array}$ & Pedunculate & Pedunculate & Subsessile & Subsessile \\
\hline $\begin{array}{l}\text { No. of flowers per } \\
\text { inflorescence }\end{array}$ & $10-15$ & $1-3$ & 4-many-flowered & 4-many-flowered \\
\hline Calyx hirsuteness & $\begin{array}{l}\text { Densely hirsute } \\
\text { externally, glabrous } \\
\text { internally }\end{array}$ & $\begin{array}{l}\text { Densely hirsute } \\
\text { externally, with } \\
\text { glandular hairs } \\
\text { internally at base } \\
\text { of lobes }\end{array}$ & $\begin{array}{l}\text { Densely hirsute } \\
\text { externally, with } \\
\text { scattered glandular } \\
\text { hairs internally and } \\
\text { prominent tufts of } \\
\text { hairs at the base }\end{array}$ & Densely hirsute \\
\hline Calyx lobes shape & Acuminate & Acuminate & $\begin{array}{l}\text { Acute or narrowly } \\
\text { acuminate }\end{array}$ & Linear \\
\hline Corolla color & White & White & $\begin{array}{l}\text { Dull reddish orange } \\
\text { or yellowish green }\end{array}$ & Red \\
\hline Corolla hirsuteness & $\begin{array}{l}\text { Glabrous externally } \\
\text { and internally }\end{array}$ & $\begin{array}{l}\text { Densely hirsute, } \\
\text { with glandular hairs } \\
\text { internally }\end{array}$ & $\begin{array}{l}\text { Glandular hairs } \\
\text { externally and } \\
\text { internally }\end{array}$ & Densely hirsute \\
\hline Calyx persistence & $\begin{array}{l}\text { Persistent entirely } \\
\text { enclosing the fruit }\end{array}$ & $\begin{array}{l}\text { Persistent entirely } \\
\text { enclosing the fruit }\end{array}$ & Not persistent & Persistent \\
\hline Style persistence & Persistent & Persistent & Not persistent & Persistent \\
\hline
\end{tabular}

recorded from material preserved in alcohol. All Philippine Cyrtandra deposited at AAH, BM, BO, E, GH, K, L, NY, P, PNH, and US were consulted through visits to these herbaria and access to digital images. Herbaria acronyms follow Index Herbariorum (Thiers, continuously updated). Descriptions follow schemes of recently published accounts of new species (Atkins \& Cronk 2001; Johnson 2017; Kartonegoro et al. 2018; Atkins et al. 2019). Assessment of Conservation Status was implemented using GeoCAT (Bachman et al. 2011), following the IUCN Red List Category criteria (IUCN Standards and Petitions Subcommittee 2017).

\section{Results}

Cyrtandra ferruginea, C. villosissima, C. hirtigera, and the new species described here share the following characteristics: erect suffrutescent habit and large slightly falcate and densely hirsute opposite leaves. There exist minute differences in their vegetative characters and they are presented in the key. Table 1 details more differences between the studied species. The studied species primarily differ, vegetatively, in color of indumentum and leaf symmetry. Cyrtandra argentti sp. nov. is distinct among the three species by having a white indumentum, and C. ferruginea is distinct by having pronouncedly anisophyllous leaves. Ultimately, the species are distinguishable by calyx and inflorescence type, corolla color and, to some degree, by geographic distribution (Fig. 1). Cyrtandra hirtigera is restricted 
to the island of Palawan and C. villosissima is found in Mindanao extending to Negros Island. Only C. ferruginea and C. argentii sp. nov. occur on Luzon island.

Class Magnoliopsida Brongn. (Brongniart 1843)

Order Lamiales Bromhead (Bromhead 1838)

Family Gesneriaceae Rich. \& Juss. (de Candolle 1816)

Genus Cyrtandra J.R.Forst. \& G.Forst. (Forster \& Forster 1775)

\section{Key to the studied species}

1. Mature leaves anisophyllous (i.e., smaller leaves less than half the length of the larger leaves in a pair)

C. ferruginea Merr.

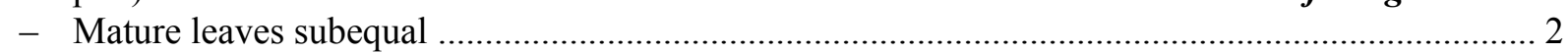

2. Indumentum white; inflorescences pendulous and pedunculate

C. argentii Olivar, H.J. Atkins \& Muellner sp. nov.

- Indumentum ferruginous; inflorescences erect and subsessile 3

3. Calyx divided almost to the base; corolla red C. villosissima Merr.

- Calyx fused for half or more of its length; corolla yellowish green or dull reddish orange

C. hirtigera H.J.Atkins \& Cronk

\section{Cyrtandra argentii Olivar, H.J.Atkins \& Muellner sp. nov. urn:lsid:ipni.org:names:77209562-1}

Figs 1, 2, 3A, 4A

\section{Diagnosis}

The species' pendulous compound cymose inflorescences (10-15 flowers) distinguish it from all other members of the genus in the Philippines. The combination of subequal leaves, white woolly indumentum, glabrous corolla, and ovoid fruit separates this species from the rest of the C. villosissima group.

\section{Etymology}

This species is named after George Argent who was part of the team that collected specimens at the type locality. George's contribution to our knowledge of the Philippine flora is undisputed. His extensive fieldwork in the country has led to the discovery of several new species, recognition of important conservation areas, and promotion of biodiversity studies.

\section{Material examined}

Type

PHILIPPINES • Mindoro Island, Oriental Province, Mt Halcon; 600 m; 13 Mar. 1997; Mendum, M., Argent, C.G.C., Pennington, R.T., Wilkie, P., Reynoso, E.J., Gaerlan, F. 29053 (holotype: E!; isotype: $\mathrm{PNH}$.

\section{Additional material}

PHILIPPINES • Mt Halcon, Mindoro; 12 May 1986; C.E. Ridsdale 1762 (K000223279, L.2822762)

• ibid.; 1 Apr. 1991; Stone, Reynoso, Sagcal 504 (K000223280, L.2822797, US00737625) • ibid.; 13 Mar. 1997; Argent, Gaerlan, Reynoso 20053 (L.3805692) - Sierra Madre Mountains, Baler Aurora; 25 Mar. 1968; Jacobs, M. 8002 (L.2822694) • Aurora National Park; 8 Mar. 1993; Barbon, Garcia, Fernando 
9121 (K000223281, L.3794225) • Llavac, Infanta, Quezon Province; 25 Jun. 1955; Lagrimas, M. 521 (L.2822646).

\section{Description}

An erect suffrutescent plant up to $3 \mathrm{~m}$ in height. Stems terete or slightly grooved, with white woolly hairs throughout. Leaves opposite, subequal; petioles 4-7 cm long, densely hirsute; blades $13-30 \times 7-15 \mathrm{~cm}$, oblong to oblong-elliptic, slightly falcate, apex attenuate, base rounded to oblique, pronouncedly asymmetrical, not decurrent, margins denticulate, 10-12 pairs of lateral veins, curving and uniting at the margins, densely hirsute on both sides. Inflorescences compound cymes, axillary, pendulous, pedunculate, with 10-15 flowers; peduncle 5-6 cm, densely hirsute; bracts green, ca $9 \times 2 \mathrm{~mm}$, lanceolate, densely hirsute on both surfaces, persistent; bracteoles on every point of branching, lanceolate, green, ca $5 \times 2 \mathrm{~mm}$, densely hirsute on both surfaces; pedicels $3-5 \mathrm{~cm}$ long, densely hirsute. Calyx tubular, pale green, ca $15 \mathrm{~mm}$ long, upper lobes ca $4 \mathrm{~mm}$ long, lower lobes ca $6 \mathrm{~mm}$ long, acuminate, densely hirsute externally, glabrous internally. Corolla white, ca $30 \mathrm{~mm}$ long, funnel-shaped, lobes suborbicular, upper lobes, $10-12 \times 5 \mathrm{~mm}$, lateral lobes $7 \times 7 \mathrm{~mm}$, lower lobes $8 \times 8 \mathrm{~mm}, 3-4 \times 1-2 \mathrm{~mm}$; glabrous externally and internally, lobes slightly recurved. Stamens 2; filaments ca $12 \mathrm{~mm}$ long, attached ca $17 \mathrm{~mm}$ from base of corolla, glabrous; anthers ca $2.5 \mathrm{~mm}$ long, thecae parallel, coherent at apices; staminodes 3 , lateral staminodes ca $3 \mathrm{~mm}$ long, central staminode ca $0.5 \mathrm{~mm}$ long. Gynoecium ca $20 \mathrm{~mm}$ long overall; disc cupular with entire margin, ca $1.5 \mathrm{~mm}$ long, glabrous; ovary ca $6 \mathrm{~mm}$ long, glabrous, with some eglandular hairs towards base of style; style ca $14 \mathrm{~mm}$ long, with eglandular hairs throughout; stigma

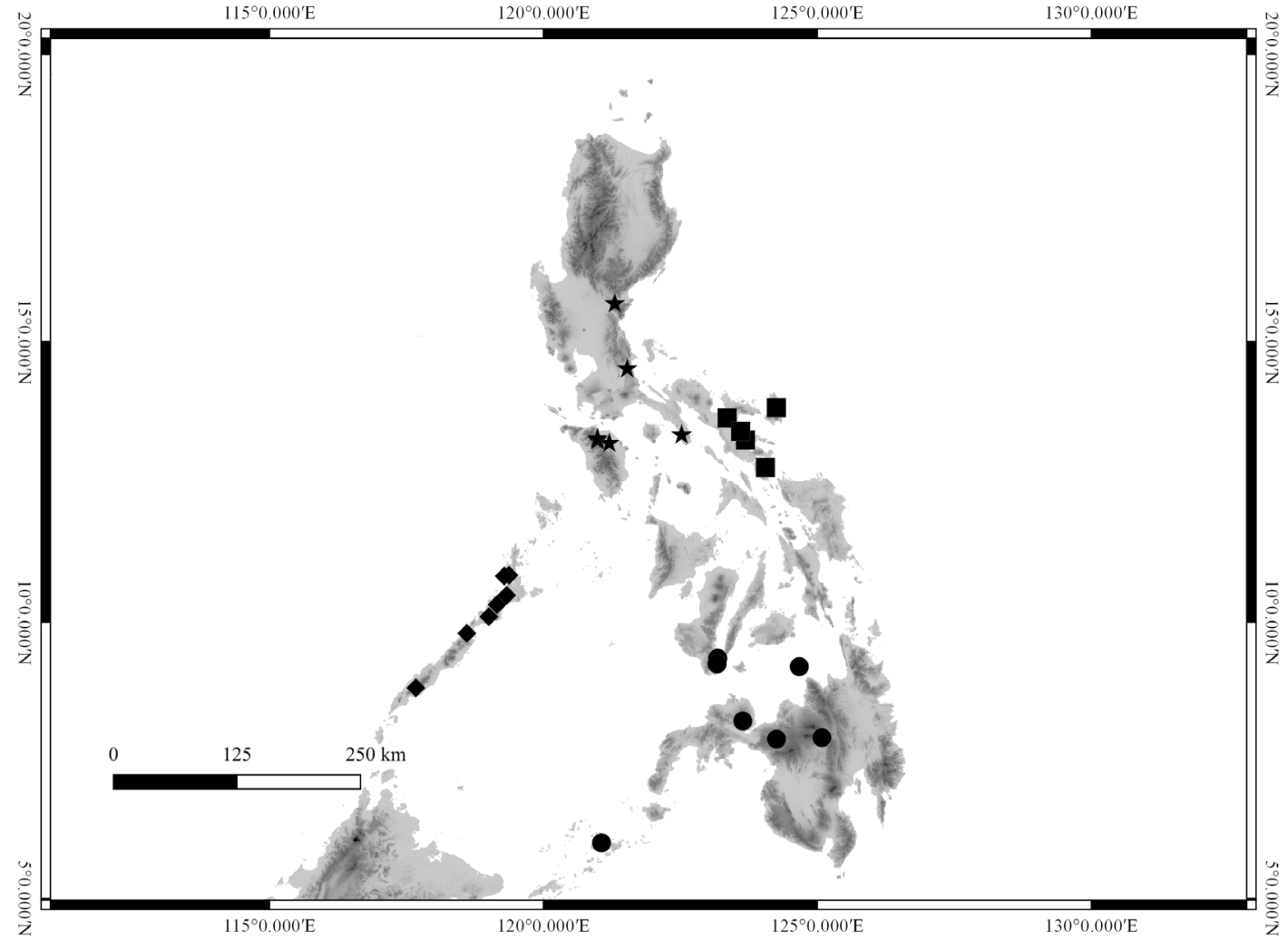

Fig. 1. Map of the Philippines showing known distributions of Cyrtandra argentii Olivar, H.J.Atkins \& Muellner sp. nov. ( $\star$ ), C. ferruginea Merr. (অ), C. hirtigera H.J.Atkins \& Cronk $(\diamond)$, and C. villosissima Merr. (O) based on collection localities. A single point may represent more than one collection. 


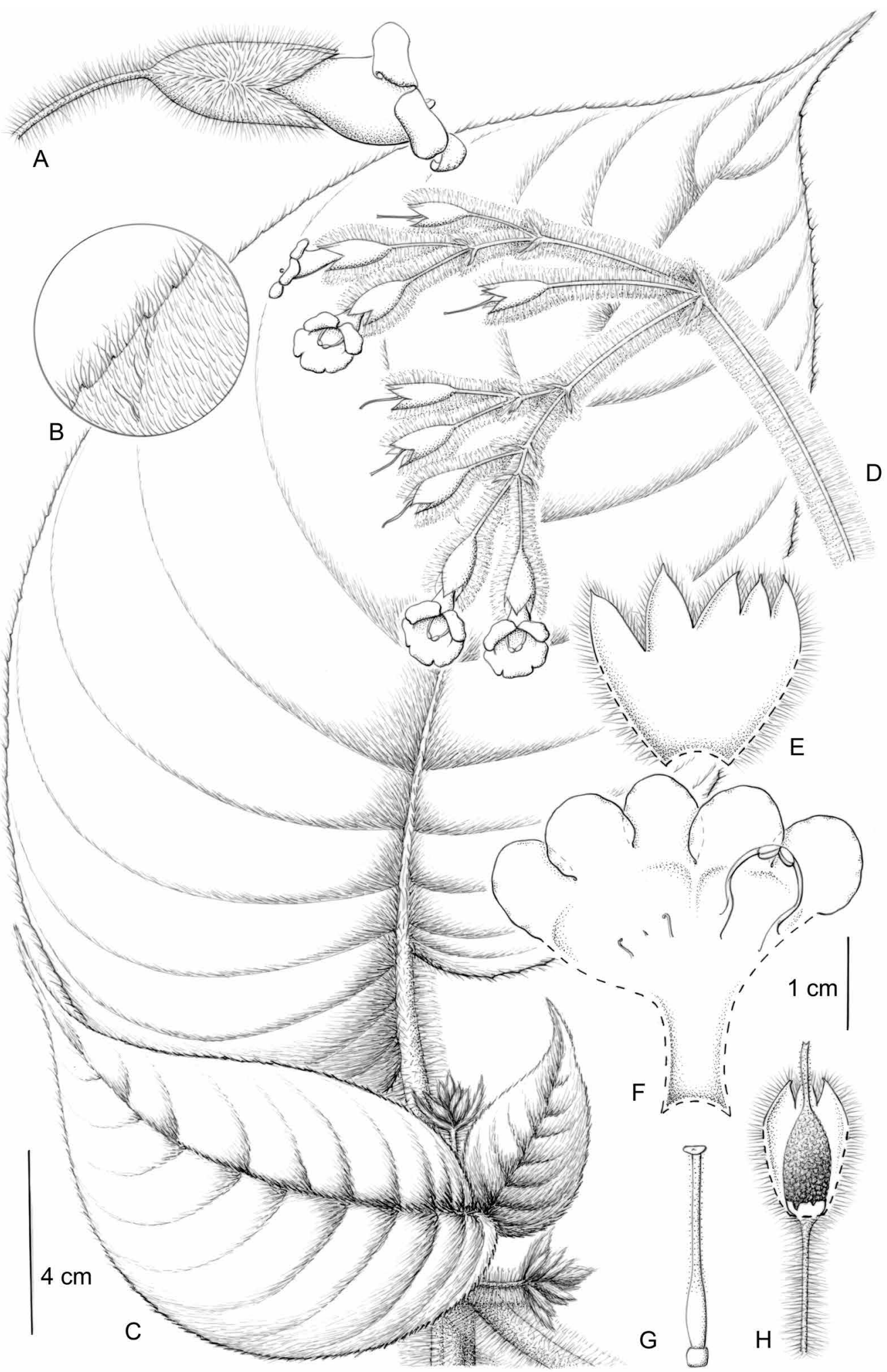

Fig. 2. Cyrtandra argentii Olivar, H.J.Atkins \& Muellner sp. nov. A. Flower, lateral view. B. Detail of upper leaf surface. C. Habit. D. Inflorescence. E. Calyx, longitudinal section. F. Corolla, longitudinal section. G. Gynoecium. H. Fruit enclosed by the persistent calyx. Drawn from Mendum et al. 29053 deposited at E. Habit, inflorescence, fruit and leaf indumentum drawn from dried material. Flower parts all from material preserved in alcohol. Drawing by Claire Banks. 
bilobed, ca $2.5 \mathrm{~mm}$ across. Fruits ovoid, green, glabrous, verrucose, ca $12 \times 5 \mathrm{~mm}$, excluding the style; calyx persistent and entirely enclosing the fruit, style persistent.

\section{Distribution and habitat}

Cyrtandra argentii sp. nov. is found growing on slopes near streams in primary forests. This species is distributed from the north of Luzon to the island of Mindoro.

\section{Conservation status}

Cyrtandra argentii sp. nov. occurs at an elevation of 600-800 $\mathrm{m}$ a.s.l. which corresponds to the forest land use zone (Villanueva \& Buot Jr 2018). Using the online GeoCAT conservation assessment tool (http://geocat.kew.org/), the proposed conservation category based on Extent of Occurrence (EOO) is Near Threatened (NT), and the category based on the estimated Area of Occupancy (AOO) calculated using the default $2 \times 2 \mathrm{~km}$ grid is Endangered (EN). Here, we consider this species' status as NT due to: i) its occurrence in close proximity to the agroforest land use zone, the latter at approximately 100-400 m a.s.l. (Villanueva \& Buot Jr 2018); and ii) the fact that the forest areas wherein the species occurs are not declared protected by law (Biodiversity Management Bureau 2015), making it highly susceptible to population decline through deforestation and other anthropogenic activities.

\section{Notes}

Like many species of Cyrtandra, filaments of $C$. argentii sp. nov. recoil into the corolla tube after anther dehiscence. This is hypothesized as constituting a mechanism against self-pollination (Bramley et al. 2003). The length of the style also varies developmentally, the style can be either exserted or inserted depending on the stage of maturity of the flower.

Cyrtandra ferruginea Merr. (Merrill 1915)

Figs 1, 3B, 4B

\section{Material examined}

Type

PHILIPPINES • Luzon, Camarines, Mt Cauayan; 9 Dec. 1913; Phil. Pl. Ramos 1548 (syntypes: BM!, GH!, NY!, P!, US!).

\section{Additional material}

PHILIPPINES • Mt Isarog, Camarines Sur; Aug. 1915; Ramos 23554 (US00081328) • ibid.; 22 Mar. 1997; Mendum et al. 29182 (E00057041) • ibid.; 23 Mar. 1997; Argent et al. 20182 (L.3805694) • Mt Bulusan, Sorsogon; Dec. 1915; Elmer 16074 (L.2818244, US00081329, U.1341267, P03884333) - ibid.; 19 Jun. 1958; Sinclair 9624 (E00631523) • Mt Mayon, Albay; 15 Nov. 1991; Reynoso, Romero \& Fuentes 3584 (E00316099) • Catanduanes; 11 Dec. 1917; Ramos 30288 (US00081330, P03884332) • Mt Malinao, Albay; 29 Oct. 1995; Reynoso, Sagcal \& Fernando 21406 (L.3805666).

\section{Description}

An erect suffrutescent plant up to $1 \mathrm{~m}$ in height. Stems terete with ferruginous hairs all throughout. Leaves opposite, anisophyllous; petioles 4-7 cm long, densely hirsute; blades ca $20 \times 12 \mathrm{~cm}$, oblong to oblong-elliptic slightly falcate, apex acute or slightly acuminate, base acute or rounded, pronouncedly asymmetrical, not decurrent, margins denticulate, 10 pairs of lateral veins, curving and uniting at the margin, densely hirsute on both sides; blades of smaller leaves of a pair $6.5-9 \times 2-2.5 \mathrm{~cm}$, resembling the major leaves in all other respects. Inflorescences cymose, axillary, erect, pedunculate, with 1-3 flowers; peduncle 2-3 cm long, densely hirsute; bracts green, ca $10 \times 1 \mathrm{~mm}$, linear lanceolate, densely hirsute 


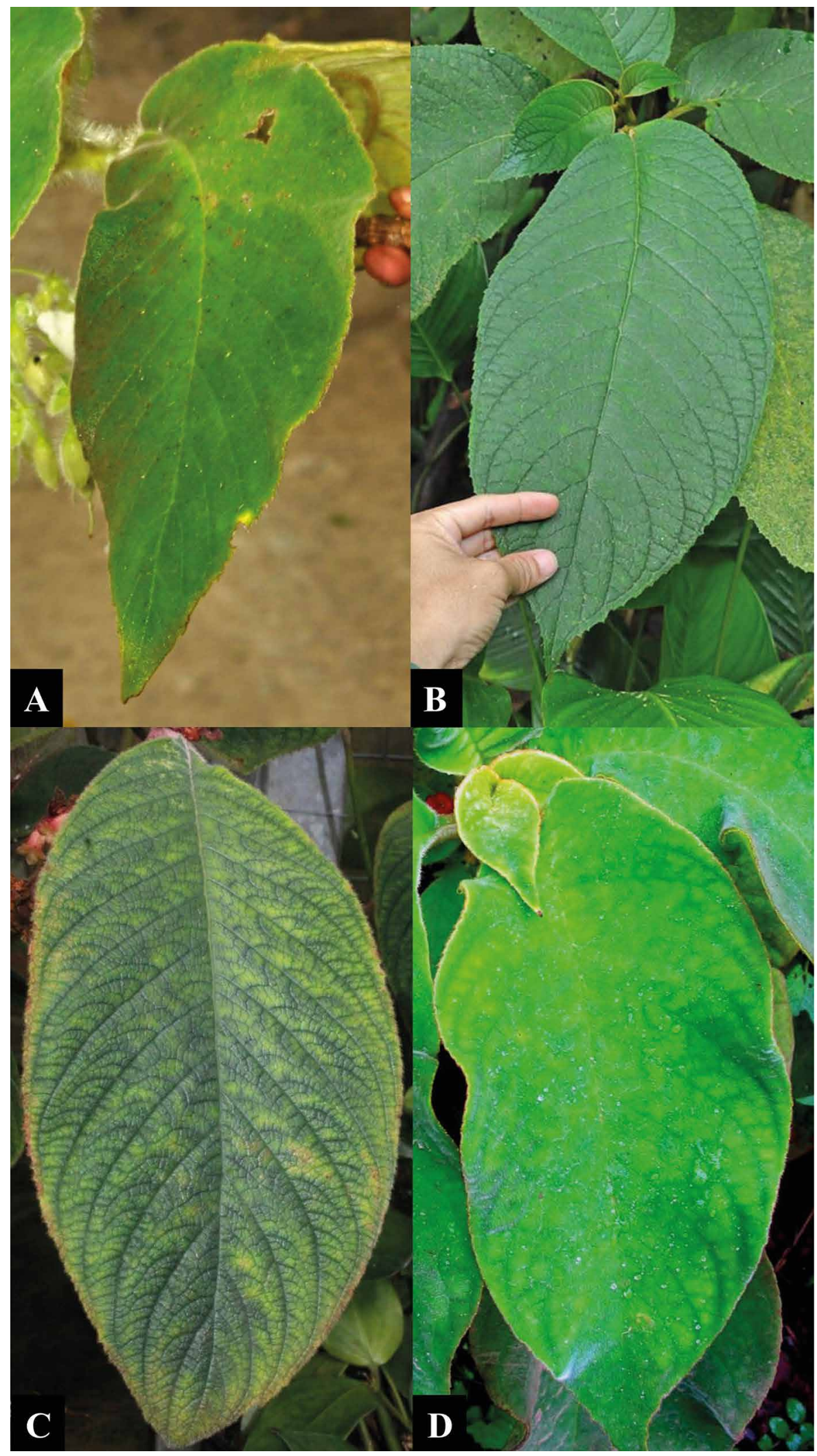

Fig. 3. Leaf similarities. A. C. argentii Olivar, H.J.Atkins \& Muellner sp. nov. B. C. ferruginea Merr. C. C. hirtigera H.J.Atkins \& Cronk. D. C. villosissima Merr. Photos taken from Co 's Digital Flora with permission (Pelser et al. 2011 onwards). 
on both surfaces, persistent. Calyx tubular, pale green, 20-30 mm long, upper lobes ca $3 \mathrm{~mm}$ long, lower lobes ca $7 \mathrm{~mm}$ long, acuminate, densely hirsute externally, with glandular hairs internally at base of lobes. Corolla white, 50-65 mm long, funnel-shaped, upper lobes rounded, ca $8 \times 9 \mathrm{~mm}$, lower and lateral lobes rounded, ca $5 \times 6 \mathrm{~mm}$, densely hirsute, with glandular hairs internally, lobes slightly recurved. Stamens 2; filaments ca $10 \mathrm{~mm}$ long, attached ca $18 \mathrm{~mm}$ from base of corolla, sparsely covered with glandular hairs; anthers ca $1.5 \mathrm{~mm}$ long, thecae parallel, coherent at apices; staminodes 3 , lateral staminodes ca $4 \mathrm{~mm}$ long, central staminode ca $1 \mathrm{~mm}$ long. Gynoecium ca $25 \mathrm{~mm}$ long overall; disc cupular with undulate margin, ca $2 \mathrm{~mm}$ long, glabrous; ovary $8-9 \mathrm{~mm}$ long, with glandular hairs throughout; style ca $12 \mathrm{~mm}$ long, with glandular hairs throughout; stigma bilobed, ca $1 \mathrm{~mm}$ across. Fruits lanceolate, green, hirsute, verrucose, $30-40 \times 6 \mathrm{~mm}$; calyx persistent and entirely enclosing the fruit, style persistent.

\section{Distribution and habitat}

Cyrtandra ferruginea is found growing in damp forests at approximately 500-800 $\mathrm{m}$ a.s.1. and can be found on Catanduanes, Mt Isarog, Mt Mayon, Mt Malinao and Mt Bulusan (Fig. 1).

\section{Notes}

Cyrtandra ferruginea is morphologically most similar to $C$. argentii sp. nov., but can be separated by the following characters: ferruginous anisophyllous leaves, 1-3 flowered simple cymes, and hirsute corolla.

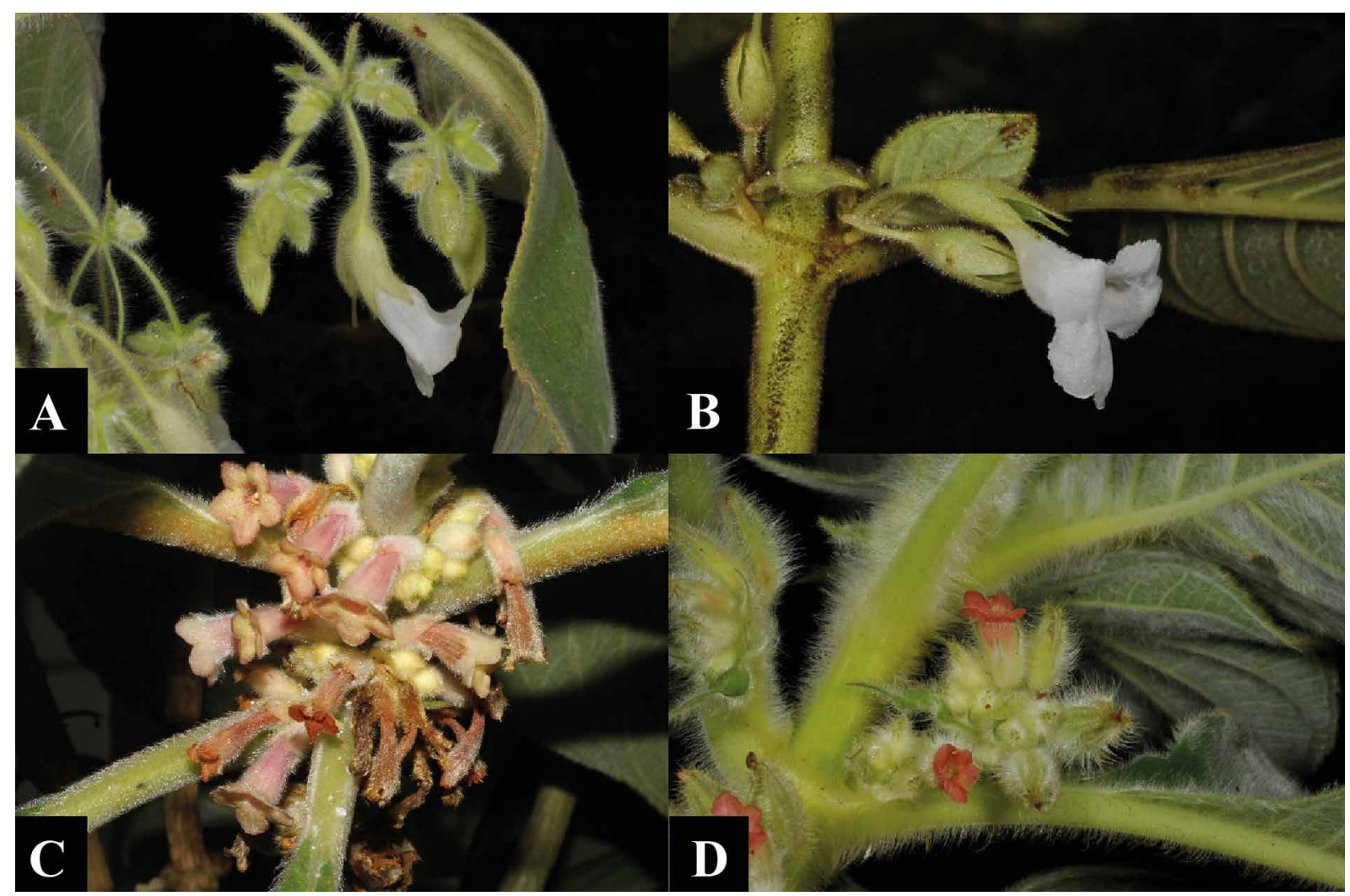

Fig. 4. Inflorescence types. A. C. argentii Olivar, H.J.Atkins \& Muellner sp. nov. B. C. ferruginea Merr. C. C. hirtigera H.J.Atkins \& Cronk. D. C. villosissima Merr. A, B \& D from Co's Digital Flora with permission (Pelser et al. 2011 onwards). C from a living collection in RBGE. 
Cyrtandra hirtigera H.J.Atkins \& Cronk (Atkins \& Cronk 2001)

Figs 1, 3C, 4C

\section{Material examined}

Type

PHILIPPINES • Palawan, Cleopatra's Needle; 29 Jan. 1998; Cronk et al. 25433 (holotype: PNH!; isotypes: $\mathrm{E}$ !, $\mathrm{K}$ !, L!).

\section{Additional material}

PHILIPPINES • San Vicente, Palawan; 4 Aug. 1988; Soejarto \& Madulid 6353 (L.2818243) • Mt Beaufort, Palawan; 12 Mar. 1984; Ridsdale SMHI 23 (L.2818051) • Pagdanan Range, Palawan; 22 Apr. 1984; Podzorski SMHI 934 (L.2818049) - Mt Mantalingahan, Palawan; 5 May 1948; Edaño 122 (L.2818048) • ibid.; 4 Mar. 1992; Argent \& Romero 9666 (L.3805814) • Malampaya Bay, Palawan; Oct. 1922; Merrill 11573 (US00081506) • Mt Capoas, Palawan; Apr. 1913; Merrill 9500 (US00081487) - Palawan; Apr. 1906; Foxworthy 581 (US00081485, P03899657) • Taytay, Palawan; 31 Jan. 1991; Stone 327 (L.2822680).

\section{Description}

An erect suffrutescent plant, up to $2-2.5 \mathrm{~m}$ in height. Stems terete, with crimson or white hairs throughout. Leaves opposite, subequal; petioles 5-8 cm long, densely hirsute; blades $22-30 \times 15-18 \mathrm{~cm}$, broadly elliptic, slightly falcate, apex acuminate, base cuneate, not decurrent, margins denticulate, 12-14 pairs of lateral veins, curving and uniting at the margins, densely hirsute on both sides. Inflorescences cymous, axillary, erect, subsessile, with 4-many flowers; peduncle 4-5 $\mathrm{mm}$, densely hirsute; bracts green, ca $1 \mathrm{~cm} \times 5 \mathrm{~mm}$, lanceolate, densely hirsute on both surfaces, persistent; bracteoles up to $5 \mathrm{~mm}$ long, densely hirsute on both surfaces; pedicels ca $5 \mathrm{~mm}$ long, densely hirsute. Calyx tubular, red or green, ca 1-1.5 cm long, lobes ca $5 \mathrm{~mm}$ long, lower lobes ca $6 \mathrm{~mm}$ long, acute or narrowly acuminate, densely hirsute externally, with scattered glandular hairs internally and has prominent tufts of hairs at the base. Corolla dull reddish orange or yellowish green, ca $2 \mathrm{~cm}$ long, funnel-shaped, lobes slightly bilabiate or subequal, upper lobes, $1-1.5 \times 2 \mathrm{~mm}$, lateral lobes $1 \times 1.5 \mathrm{~mm}$, lower lobes $2 \times 1.5 \mathrm{~mm}$; glandular hairs externally and internally. Stamens 2 ; filaments ca $1-1.5 \mathrm{~cm}$ long, attached ca $12-13 \mathrm{~mm}$ from base of corolla, glabrous; anthers ca $2 \mathrm{~mm}$ long, thecae parallel, coherent at apices; staminodes 2, 5-8 $\mathrm{mm}$ long. Gynoecium ca $20 \mathrm{~mm}$ long overall; disc cupular with undulate margin, ca $1.5 \mathrm{~mm}$ long, glabrous; ovary ca 4-5 mm long, glabrous; style ca $10 \mathrm{~mm}$ long, with eglandular hairs throughout; stigma bilobed, ca $2.5 \mathrm{~mm}$ across. Fruits ovoid, green, glabrous, ca $1 \mathrm{~cm} \times 5 \mathrm{~mm}$; inflorescence bracts persistent, calyx and style not persistent.

\section{Distribution and habitat}

Cyrtandra hirtigera is distributed throughout the island of Palawan and is usually found on slopes near gullies at 30-900 $\mathrm{m}$ a.s.1.

\section{Notes}

Atkins \& Cronk (2001) described two varieties of this species, $C$. hirtigera var. hirtigera and C. hirtigera var. chlorina, distinguishable by color and shape of their calyces and corolla limbs. Cyrtandra hirtigera var. hirtigera has a crimson indumentum, red calyces with acute lobe apices, and reddish orange corollas with slightly bilabiate limbs. Cyrtandra hirtigera var. chlorina has pale indumentum, green calyces with acuminate lobe apices, and yellowish green corollas with subequal lobes. 


\section{Material examined}

Type

PHILIPPINES • Mindanao, Camp Keithley, Lake Lanao; Jan. 1906; Mrs Clemens 51 (holotype: AAH!; isotypes: F!, US!).

\section{Additional material}

PHILIPPINES • Mt Malindang, Misamis Occidental; 16 Mar. 2004; Opiso et al. 2088 (L.3794253) - ibid.; May 1993; Gaerlan et al. 10925 (K000184579, L.3794112) • Mt Hibok-Hibok, Camiguin; 1999; RBGE \& PNH 48 (E00743749) - Lake Balunsasayao, Negros Oriental; 11 Sep. 1953; Britton 357 (L.2826671) • Cuernos Mountains, Negros Oriental; 13 May 1948; Edaño 7393 (AAH00092001) - ibid.; Mar. 1908; Elmer 9511 (L.2826672, US00081486) • Mahilucot River, Bukidnon; Jul. 1920; Ramos \& Edaño 38649 (L.2826670, US00081488) • Mt Daho, Jolo; Sep. 1924; Ramos \& Edaño 43913 (P03899658).

\section{Description}

Anerectsuffrutescentplant up to $7 \mathrm{minheight}$. Stems tereteor slightly grooved, with ferruginous woolly hairs throughout. Leaves opposite, subequal; petioles 3-5 cm long, densely hirsute; blades $11-20 \times 3.5-8 \mathrm{~cm}$, oblong-ovate to ovate-lanceolate, slightly falcate, apex acuminate, base acute or acuminate, pronouncedly asymmetrical, not decurrent, margins denticulate, 12-14 pairs of lateral veins, curving and uniting at the margins, densely hirsute on both sides. Inflorescences cymous, axillary, erect, subsessile, with 4-many flowers; peduncle 4-5 mm, densely hirsute; bracts green, ca $1 \mathrm{~cm}$, linear, densely hirsute on both surfaces, persistent; bracteoles up to $5 \mathrm{~mm}$ long, densely hirsute on both surfaces; pedicels ca $5 \mathrm{~mm}$ long, densely hirsute. Calyx tubular, pale green, lobes linear ca $1.5 \mathrm{~cm} \times 1 \mathrm{~mm}$, densely hirsute. Corolla red, ca $18 \mathrm{~mm}$ long, funnel-shaped, lobes orbicular-ovate ca $4 \mathrm{~mm}$ long, densely hirsute. Stamens 2; filaments ca $2 \mathrm{~mm}$ long; anthers ca $2.5 \mathrm{~mm}$ long, thecae parallel, coherent at apices. Gynoecium ca $20 \mathrm{~mm}$ long overall, densely hirsute; disc cupular, glabrous; style densely hirsute. Fruits oblong, green, densely hirsute, ca $1 \mathrm{~cm} \times 4.5 \mathrm{~mm}$; calyx and style persistent.

\section{Distribution and habitat}

Cyrtandra villosissima is distributed throughout the island of Mindanao and extends to the island of Negros in the Visayas and is usually found in well-shaded areas near ravines.

\section{Notes}

Cyrtandra villosissima is vegetatively similar to $C$. hirtigera. It is distinguishable by its red corolla and green calyces with distinctly linear lobes. Based on available distribution data, $C$. hirtigera appears to be restricted to the island of Palawan while C. villosissima can be found from Negros Island to the island of Mindanao.

\section{Discussion}

The recognition of $C$. argentii sp. nov. as a new species was here aided by increased availability of collections with reproductive parts and continued alpha-taxonomic work. This highlights the importance of reproductive characters in establishing species boundaries among Cyrtandra species. In phylogenetic analyses of the Southeast Asian Cyrtandra (Atkins et al. 2020), the C. villosissima group was not resolved as monophyletic; only $C$. villosissima and $C$. hirtigera belonged to the same subclade, but were not resolved as exclusive sister taxa. The character combination of erect suffrutescent habit with large leaves that are slightly falcate and densely hirsute has evolved at least three times independently (Atkins 
et al. 2020). Figure 3 shows this shared character combination and Fig. 4 shows the inflorescence type that ultimately distinguishes the species from each other.

The genus Cyrtandra is the most taxonomically challenging in the Gesneriaceae due to its large number and high proportion of poorly known and undescribed species (Burtt 2001; Atkins et al. 2013; Clark et al. 2013). Atkins et al. (2013) estimated 800 species of Cyrtandra. Since then, several authors (Bone \& Atkins 2013; Johnson 2017; Kartonegoro et al. 2018; Atkins et al. 2019) have described additional species. The number of species is expected to increase further as more alpha-taxonomic work and field collection are carried out.

Large genera can be systematically addressed by following a phylogenetically informed taxonomic approach on a region-by-region basis (Atkins et al. 2013; Clark et al. 2013). This has been applied effectively by Bramley (2005) in a revision of Cyrtandra section Dissimiles in Borneo. The approach involves a robustly sampled phylogenetic tree wherein monophyletic clades can be characterized morphologically by one or more salient characters (Atkins et al. 2013; Clark et al. 2013). Taxa with molecular data can be assigned to the clades while taxa lacking molecular data can be tentatively assigned based on morphological similarities. Upon assignment to a clade, taxonomic assessment can be streamlined by focusing on related taxa identified through both morphological and molecular data, therefore limiting the number of potential conspecifics for comparison. Areas, particularly archipelagos, with high diversity can benefit from this approach since it provides a systematic way of prioritizing areas where additional fieldwork and alpha-taxonomic work are most needed. Clark et al. (2013) suggest that phylogenetically defined areas can be addressed taxonomically first, followed by increased sampling in lesser-resolved areas. This strategy is currently being applied to study the genus in the Philippines with the aim of producing a complete revision of Cyrtandra in the archipelago (Olivar et al., in preparation).

\section{Acknowledgements}

This research received support from the SYNTHESYS Project http://www.synthesys.info/ which is financed by European Community Research Infrastructure Action under the FP7 'Capacities' Program. Financial support for this study was also provided by the Deutscher Akademischer Austauschdienst (DAAD project no. 91690870) to JECO and ANM-R, and the Federal Ministry of Education and Research (BMBF project no. 16GW0120K) to ANM-R. Mr Danilo Tandang from PNH is acknowledged for his help with the types. Curators of AAH, BM, BO, E, GH, K, L, NY, P, PNH, and US are acknowledged for their assistance during visits, loans, and digital images. Nathan Kelso, Sadie Barber and Stephen Willis are thanked for their excellent care of the Gesneriaceae living collections at RBGE and Claire Banks is thanked for the detailed botanical illustration of the new species.

\section{References}

Atkins H.J. 2004. The Gesneriaceae of Sulawesi II: Seven new species of Cyrtandra. Edinburgh Journal of Botany 60 (3): 305-321. https://doi.org/10.1017/s096042860300026x

Atkins H.J., Bramley G.L.C. \& Clark J.R. 2013. Current knowledge and future directions in the taxonomy of Cyrtandra (Gesneriaceae), with a new estimate of species number. Selbyana 31 (2): 157165. Available from https://www.jstor.org/stable/24894287 [accessed 2 Jun. 2020].

Atkins H.J., Bramley G.L.C, Johnson M.A., Kartonegoro A., Nishii K., Kokubugata G., Möller M. \& Hughes M. 2020. A molecular phylogeny of Southeast Asian Cyrtandra (Gesneriaceae) supports an emerging paradigm for Malesian plant biogeography. Frontiers of Biogeography 12 (1). https://doi.org/10.21425/F5FBG44184

Atkins H.[J.] \& Cronk Q.C.B. 2001. The genus Cyrtandra (Gesneriaceae) in Palawan, Philippines. Edinburgh Journal of Botany 58 (3): 443-458. https://doi.org/10.1017/s0960428601000762 
Atkins H.J., Heatubun C.D., Galloway L. \& Bramley G.L.C. 2019. Two new species, Cyrtandra bungahijau and C. vittata, and notes on Cyrtandra (Gesneriaceae) from Yapen Island, Indonesia. Kew Bulletin 74 (2): 29. https://doi.org/10.1007/s12225-019-9817-2

Atkins H.[J.], Preston J. \& Cronk Q.C.B. 2001.Amolecular test ofHuxley's line: Cyrtandra (Gesneriaceae) in Borneo and the Philippines. Biological Journal of the Linnean Society 72 (1): 143-159.

https://doi.org/10.1111/j.1095-8312.2001.tb01306.x

Bachman S., Moat J., Hill A.W., De Torre J. \& Scott B. 2011. Supporting Red List threat assessments with GeoCAT: geospatial conservation assessment tool. ZooKeys (150): 117-126.

https://doi.org/10.3897/zookeys.150.2109

Biodiversity Management Bureau. 2015. Guidebook to Protected Areas of the Philippines. Biodiversity Management Bureau, Department of Environment and Natural Resources, Quezon City.

Bone R.E. \& Atkins H.J. 2013. Four new species of Cyrtandra (Gesneriaceae) from the Latimojong Mountains, South Sulawesi. Edinburgh Journal of Botany 70 (3): 455-468.

https://doi.org/10.1017/s0960428613000152

Bramley G.L.C. 2005. Revision of Cyrtandra section Dissimiles (Gesneriaceae). Blumea - Biodiversity, Evolution and Biogeography of Plants 50 (1): 163-189. https://doi.org/10.3767/000651905x623355

Bramley G.L.C., Weber A., Cronk Q.C.B. \& Bokhari M.H. 2003. The genus Cyrtandra (Gesneriaceae) in Peninsular Malaysia and Singapore. Edinburgh Journal of Botany 60 (3): 331-360.

https://doi.org/10.1017/s0960428603000283

Bramley G.L.C., Pennington R.T., Zakaria R., Tjitrosoedirdjo S.S. \& Cronk Q.C.B. 2004. Assembly of tropical plant diversity on a local scale: Cyrtandra (Gesneriaceae) on Mount Kerinci, Sumatra. Biological Journal of the Linnean Society 81 (1): 49-62. https://doi.org/10.1111/j.1095-8312.2004.00283.x

Bromhead E.F. 1838. Lamiales. Magazine of Natural History 2: 210.

Brongniart A.T. 1843. Magnoliopsida. Énumération des Genres de Plantes cultivés au Muséum d'histoire naturelle de Paris xxvi: 95.

Burtt B.L. 1970. Studies in the Gesneriaceae of the Old World. XXXIII. Some species of Cyrtandra, chiefly Bornean. Notes Royal Botanic Garden Edinburgh 30: 23-42.

Burtt B.L. 2001. A survey of the genus Cyrtandra (Gesneriaceae). Phytomorphology Golden Jubilee Issue 51: 393-404.

Candolle A. de \& Candolle C. de 1883. Monographice phanerogamarum: Prodromi nunc continuatio, nunc revisio. Vol. 1-8, G. Masson; vol. 9, Masson \& Cie, Paris.

Candolle A.P. de. 1816. Essai sur les propriétés médicales des plantes, comparées avec leurs formes extérieures et leur classification naturelle. Crochard, Paris. https://doi.org/10.5962/bhl.title.112422

Clark J.R., Atkins H.J., Bramley G.L.C., Jolles D.D., Roalson E.H. \& Wagner W.L. 2013. Towards a phylogenetically informed taxonomy of Cyrtandra (Gesneriaceae) in the Solomon Islands. Selbyana 31 (2): 166-183.

Clark J.R., Wagner W.L. \& Roalson E.H. 2009. Patterns of diversification and ancestral range reconstruction in the southeast Asian-Pacific angiosperm lineage Cyrtandra (Gesneriaceae). Molecular Phylogenetics and Evolution 53 (3): 982-994. https://doi.org/10.1016/j.ympev.2009.09.002

Cronk Q.C., Kiehn M., Wagner W.L. \& Smith J.F. 2005. Evolution of Cyrtandra (Gesneriaceae) in the Pacific Ocean: the origin of a supertramp clade. American Journal of Botany 92 (6): 1017-1024.

Elmer A.D.E. 1913. Four scores of new plants. Leaflets of Philippine Botany V: 1751-1853. 
Forster J.R. \& Forster J.G.A. 1775. Cyrtandra. Characteres Generum Plantarum 3.

Gillett G.W. 1967. The genus Cyrtandra in Fiji. Contributions from the United States National Herbarium 37 (4): 107-159.

IUCN Standards and Petitions Subcommittee. 2017. Guidelines for Using the IUCN Red List Categories and Criteria Version 13. Prepared by the Standards and Petitions Subcommittee. Gland, Switzerland and Cambridge, U.K.

Johnson M.A. 2017. Four new species of Cyrtandra (Gesneriaceae) from the South Pacific Islands of Fiji. PhytoKeys 91: 85-104. https://doi.org/10.3897/phytokeys.91.21623

Johnson M.A., Clark J.R., Wagner W.L. \& McDade L.A. 2017. A molecular phylogeny of the Pacific clade of Cyrtandra (Gesneriaceae) reveals a Fijian origin, recent diversification, and the importance of founder events. Molecular Phylogenetics and Evolution 116: 30-48.

https://doi.org/10.1016/j.ympev.2017.07.004

Johnson M.A., Pillon Y., Sakishima T., Price D.K. \& Stacy E.A. 2019. Multiple colonizations, hybridization and uneven diversification in Cyrtandra (Gesneriaceae) lineages on Hawai'i Island. Journal of Biogeography 46 (6): 1178-1196. https://doi.org/10.1111/jbi.13567

Kartonegoro A., Bone R. \& Atkins H. 2018. Eleven new species of Cyrtandra (Gesneriaceae) from Sulawesi, Indonesia. Edinburgh Journal of Botany 75 (2): 173-204.

https://doi.org/10.1017/S0960428618000045

Lorence D.H. \& Perlman S. 2007. A new species of Cyrtandra (Gesneriaceae) from Hawai'i, Hawaiian Islands. Novon: A Journal for Botanical Nomenclature 17 (3): 357-361.

https://doi.org/10.3417/1055-3177(2007)17[357:ANSOCG]2.0.CO;2

Merrill E.D. 1906. New or noteworthy Philippine plants, V. Philippine Journal of Science 1 (Supplement): 169-246.

Merrill E.D. 1915. New or noteworthy Philippine plants, XI. The Philippine Journal of Science. Section C, Botany 10: 1-84.

Merrill E.D. 1922. An Enumeration of Philippine Flowering Plants. Bureau of Printing, Manila.

Nishii K., Kokubugata G., Möller M. \& Atkins H.J. 2019. Notes on Cyrtandra (Gesneriaceae) from Japan, Taiwan and Batan Island (Philippines). Edinburgh Journal of Botany 76 (3): 333-344.

https://doi.org/10.1017/s0960428619000106

Pelser P.B., Barcelona J.F. \& Nickrent D.L. 2011 onwards. Co 's Digital Flora of the Philippines [online]. Available from www.philippineplants.org [accessed 2 May 2019].

Thiers B. continuously updated. Index Herbariorum [online].

Available from http://sweetgum.nybg.org/science/ih/ [accessed 5 May 2019].

Villanueva E.L.C. \& Buot Jr I.E. 2018. Vegetation analysis along the altitudinal gradient of Mt Ilong, Halcon Range, Mindoro Island, Philippines. Biodiversitas Journal of Biological Diversity 19 (6): 2163 2174. https://doi.org/10.13057/biodiv/d190624

Wagner W.L., Wood K.R. \& Lorence D.H. 2001. A new species of Cyrtandra (Gesneriaceae) from Kaua'i, Hawaiian Islands. Novon 11 (1): 146-152. https://doi.org/10.2307/3393224 
Manuscript received: 2 September 2019

Manuscript accepted: 6 January 2020

Published on: 30 June 2020

Topic editor: Frederik Leliaert

Desk editor: Connie Baak

Printed versions of all papers are also deposited in the libraries of the institutes that are members of the EJT consortium: Muséum national d'histoire naturelle, Paris, France; Meise Botanic Garden, Belgium; Royal Museum for Central Africa, Tervuren, Belgium; Royal Belgian Institute of Natural Sciences, Brussels, Belgium; Natural History Museum of Denmark, Copenhagen, Denmark; Naturalis Biodiversity Center, Leiden, the Netherlands; Museo Nacional de Ciencias Naturales-CSIC, Madrid, Spain; Real Jardín Botánico de Madrid CSIC, Spain; Zoological Research Museum Alexander Koenig, Bonn, Germany; National Museum, Prague, Czech Republic. 